\title{
A REVOLUTION IN IOWA: THE CORN PICKER
}

Patrick J. Lawler, a young Wall Lake farm boy, did not particularly care for the farm. He dreaded the tedious task of hand-picking corn each year. He experienced, first-hand, the fatigue that accompanied the process and knew well the strain placed upon all men who had to handpick their crops.

Because of his interest in machinery, Lawler set about experimenting with a machine that would eliminate picking corn by hand. With the aid of a young lawyer friend, John F. Barry, Lawler built a model of a mechanized corn picker and then went on to build a full-scale working model. In 1885 , the partners demonstrated for the first time this laborsaving device which revolutionized corn harvesting in Iowa as well as in all the corn belt! Patent papers were issued to the two men by the U. S. Patent Office on April 15, 1890.

An all metal machine, the operating parts of this corn picker were attached to the axle-shaft of two large, metalspoked wheels. The main part of the machine was a kind of elevator chute, with the head of the chute opening near the ground. A set of chains with metal hooks turned inward inside the mouth and pulled the corn stalks into the machine. Today, this is called the "gathering chain."

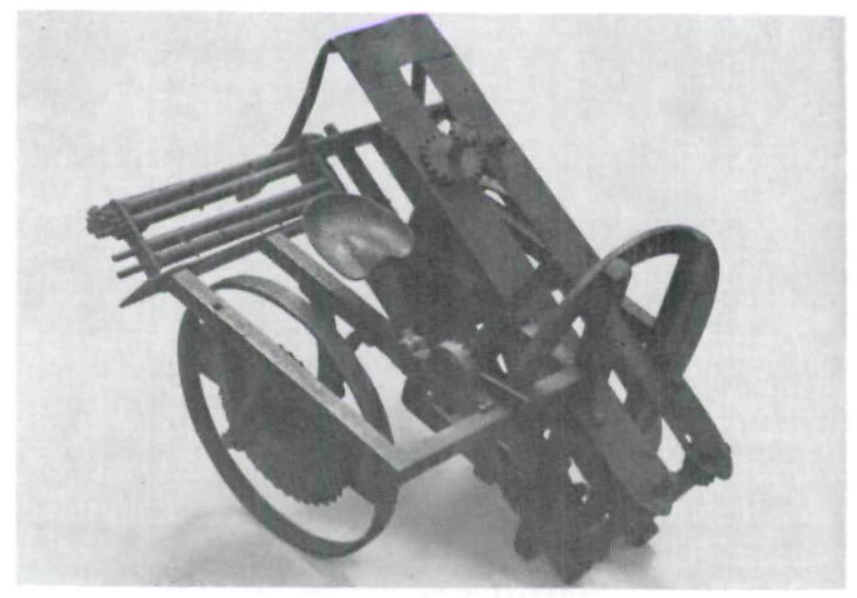

photo by Jobn Pbipps

Model of Early Corn Picker 
The chute was tilted, with the jaws near the ground, so that the stalks came off the chain into a set of rollers which separated the ears from the stalk. These are now called the "snapping rolls."

The ears dropped next on to other rollers which looked much like rolling pins dotted with small wooden pegs, except they were all metal. These are "husking rollers." The same basic principles are applied in today's modern corn pickers.

Although the machine broke down on the first trial run in 1885, it worked again after a few repairs. Lawler and Barry were offered a large sum for their picker from a farm machinery manufacturing company in Chicago, but they declined the offer in hopes of manufacturing the machine themselves. However, their attempts at big industry were not successful. Eventually, Lawler's original machine was sold for scrap iron in 1932.

The Iowa State Department of History and Archives now has possession of the original patent papers issued to Lawler and Barry. A model of the corn picker is on display on the second floor of the museum.

\section{WALNUT CATSUP . . .}

Research for an Iowa state fair article revealed the fact that for several years walnut catsup was awarded premiums in the "pantry stores" division. The following is an 1831 recipe from The Williamsburg Art of Cookery by Mrs. Helen Bullock (Richmond, Va., 1940):

The Walnuts should be gathered when the Nut is so young that you can run a Pin into it easily; pour boiling Salt and Water on, and let them be covered with it nine Days, changing it every third Day; then pound them in a Marble Mortar - to every Dozen Walnuts, put a Quart of Vinegar; stir them well every Day for a Week, then put them in a Bag, and press all the Liquor through; to each Quart, put a Teaspoonful of pounded Cloves, and one of Mace, with six Cloves of Garlic - boil it fifteen or twenty Minutes, and bottle it. 
Copyright of Annals of Iowa is the property of State of Iowa, by \& through the State Historical Society of Iowa and its content may not be copied or emailed to multiple sites or posted to a listserv without the copyright holder's express written permission. However, users may print, download, or email articles for individual use. 